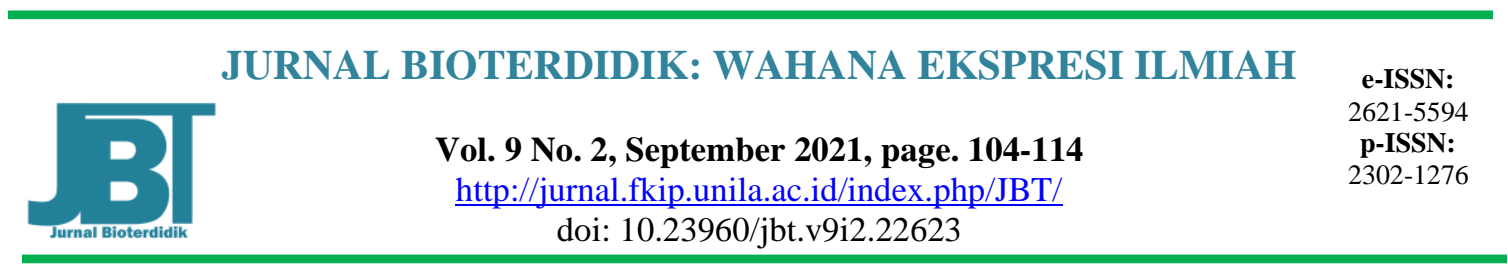

\title{
Pengembangan Modul Biologi SMA Kelas X Berbasis Etnobotani Masyarakat Kediri dan Sekitarnya Untuk Meningkatkan Hasil Belajar Siswa
}

\author{
Anita Ernawati, Sulifah Aprilya Hariani, Siti Murdiyah \\ Pendidikan Biologi, Fakultas Keguruan dan Ilmu Pendidikan, Universitas Jember, Jl. Kalimantan 37 \\ Kampus Tegalboto Jember, Indonesia \\ *e-mail: anitaernawati82@gmail.com
}

\begin{abstract}
Development of Biology Teaching Materials for Class X Senior High School Based on Ethnobotany in Kediri and Surrounding Communities to Improve Student Learning Outcomes. The purpose of this study is to produce high school biology modules based on the ethnobotany of the people in Kediri and its surroundings to improve student learning outcomes. The development research used the Borg and Gall model which was tested on students of SMAN 1 Plemahan. Based on the results of the material expert validator's assessment, the percentage is $98.82 \%$; according to development experts by 80\%; according to media experts by 88\%; and according to user experts the percentage is $95.25 \%$. The results of the four expert validators are each at a very valid level. The results of the practicality test are $97.5 \%$ and interpreted in the very practical category. The results of the effectiveness test have an average $N$-gain of 0.58 with moderate criteria in the category of quite effective for improving student learning outcomes.
\end{abstract}

Keywords: ethnobotany, development, module, learning outcomes

\begin{abstract}
Abstrak: Pengembangan Modul Biologi SMA Kelas X Berbasis Etnobotani Masyarakat Kediri dan Sekitarnya Untuk Meningkatkan Hasil Belajar Siswa. Penelitian ini bertujuan untuk menghasilkan modul biologi SMA berbasis etnobotani masyarakat Kediri dan sekitarnya untuk meningkatkan hasil belajar siswa. Penelitian pengembangan menggunakan model Borg and Gall yang diujicobakan pada siswa SMAN 1 Plemahan. Berdasarkan hasil penilaian validator ahli materi persentasenya sebesar 98,82\%; menurut ahli pengembangan sebesar $80 \%$; menurut ahli media sebesar $88 \%$; dan menurut ahli pengguna persentasenya sebesar $95,25 \%$. Hasil dari keempat validator ahli masing-masing berada pada tingkat sangat valid. Hasil dari uji kepraktisan yaitu sebesar 97,5\% dan diinterpretasikan dalam kategori sangat praktis. Hasil dari uji keefektifan memiliki rata-rata $\mathrm{N}$-gain sebesar 0,58 dengan kriteria sedang yang termasuk dalam kategori cukup efektif untuk meningkatkan hasil belajar siswa.
\end{abstract}

Kata kunci: pengembangan, modul, etnobotani, hasil belajar 


\section{PENDAHULUAN}

Indonesia merupakan negara yang kaya akan keanekaragaman hayati serta dilengkapi dengan keanekaragaman budaya dari berbagai etnik masyarakat setempat sebagai sumber daya lokal. Setiap etnik memiliki suatu pengetahuan lokal untuk pemanfaatan dan pelestarian sumber daya lokal dilingkungan setempat. Salah satu sumberdaya alam yang dimanfaatkan oleh masyarakat yaitu berkaitan dengan ilmu etnobotani. Etnobotani lebih memfokuskan pada manusia, alam dan tumbuhan dalam konteks budaya. Masyarakat banyak yang memanfaatkan tumbuhan sebagai sandang, pangan, papan dan keperluan lainnya (Hafida et al., 2020). Tetapi untuk saat ini, sebagian besar masyarakat lebih tertarik dengan memanfatkan sumber alternatif dikarenakan lebih praktis dan modern jika dibandingkan dengan kearifan lokal tumbuhan tradisional dalam memenuhi kebutuhan hidupnya. Hal tersebut akan berdampak pada menurunnya pengetahuan Etnobotani dalam masyarakat. Seiring dengan perkembangan zaman, karakter masyarakat perlu ditingkatkan untuk mempertahankan kearifan lokal budaya agar tetap lestari.

Penguatan karakter ini salah satunya dapat dilakukan melalui pendidikan terutama dalam pembelajaran. Pendekatan kearifan lokal dan budaya dengan menerapkan dan memberikan pengetahuan Etnobotani kepada generasi muda disekolah, yaitu dengan menintegrasikan nilai-nilai kearifan lokal dan budaya sekitar sekolah (tempat tinggal siswa dan sekitarnya). Pembelajaran biologi berbasis kearifan lokal juga dapat digunakan sebagai pembelajaran mengenai sumber daya alam yang wajib diketahui, dipahami dan dilestarikan oleh generasi muda melalui pendidikan (Alimah, 2019). Hal ini selaras dengan Kurikulum 2013, apabila guru dan siswa dalam melakukan pembelajaran memilih pendekatan sesuai dengan potensi siswa dan lingkungan sekitar maka pembelajaran akan lebih mengena dan bermakna bagi siswa (Adinugraha et al., 2020). Pendekatan kearifan lokal dan budaya ini memiliki kelebihan yaitu siswa dan guru menjadikan pengetahuan etnobotani dalam pembelajaran Biologi berupa kearifan lokal dan budaya sebagai salah satu pedoman sehari-hari (Adinugraha \& Ratnapuri, 2020).

Bahan ajar merupakan salah satu aspek penting dalam lingkup pendidikan. Bahan ajar ini salah satu sarana yang digunakan untuk mendukung berjalannya proses kegiatan belajar dan mengajar oleh guru di kelas (Khulsum et al., 2019). Bahan ajar yang digunakan di sekolah masih belum terintegrasi dengan sumber lain seperti potensi lingkungan yang ada di sekitar berupa nilai kearifan lokalnya. Salah satu cara yang dapat dilakukan yaitu dengan menyisipkan pada mata pelajaran Biologi pokok bahasan Tumbuhan (Plantae). Hal tersebut telah diketahui berdasarkan hasil kuisioner kebutuhan dari guru, siswa dan pengkaji budaya. Bahan ajar yang dikembangkan dalam penelitian ini berupa modul Biologi SMA kelas X. Materi yang ditambahkan yaitu materi khusus tentang pengetahuan manfaat tumbuhan sebagai bahan obat tradisional dan acara adat istiadat oleh masyarakat Suku Jawa di Kabupaten Kediri dan sekitarnya. Modul merupakan salah satu bahan ajar yang memiliki susunan sistematis dan bahasa yang mudah dipahami oleh siswa (Soleh et al., 2020). Untuk menciptakan hasil belajar yang optimal dapat diperoleh dari belajar mandiri siswa yang memerlukan bahan atau materi pembelajaran yang tepat atau sesuai dengan tujuan pembelajaran. Untuk mengembangkan kemampuan siswa secara mandiri maupun semi mandiri dapat menggunakan modul (Yermon \& Eliza, 2020). Penelitian ini bertujuan untuk mengembangkan dan menguji modul Biologi SMA berbasis etnobotani masyarakat 
Kediri dan sekitarnya yang teruji valid, praktis dan efektif untuk meningkatkan hasil belajar siswa.

\section{METODE}

Jenis penelitian yang digunakan merupakan jenis penelitian pengembangan (Research and Development). Penelitian ini dilakukan 10 Desember 2020 sampai 23 April 2021. Penelitian ini dilaksanakan di Kabupaten Kediri, Nganjuk, Jombang dan Blitar. Untuk uji coba di SMA Negeri 1 Plemahan, yaitu salah satu SMA Negeri yang ada di Kecamatan Plemahan Kabupaten Kediri. Subjek dalam penelitian ini adalah siswa kelas X. Teknik pengumpulan data dapat dilakukan dengan berbagai cara, yaitu observasi, wawancara, penyebaran angket/kuisioner, studi literatur dan dokumentasi. Studi literatur untuk mengkaji hasil penelitian terdahulu guna mengetahui keluasan dan kedalaman modul yang akan dikembangkan sesuai dengan kondisi siswa serta tujuan dari pembelajaran. Data lain yang dihasilkan berupa data validasi, keterbacaan (cloze test), respon siswa dan hasil belajar (pre-test dan post-test).

Metode penelitian pengembangan merupakan metode penelitian yang digunakan untuk menghasilkan dan menguji keefektifan suatu produk. Berdasarkan desain penelitian yang disusun, model pengembangan yang digunakan dalam penelitian ini yaitu model Borg and Gall. Prosedur penelitian pengembangan dengan memodifikasi yaitu menggunakan 7 dari 10 langkah pengembangan Borg and Gall. 7 langkah yang digunakan dengan tujuan penelitian pengembangan yaitu langkah Studi pendahuluan dan pengumpulan data (research and information collecting), Perencanaan (planning), Mengembangkan produk awal (develop preliminary from of product), Uji Coba Lapangan Awal (Uji Coba Skala Kecil) (Preliminary Field Testing), Revisi untuk Menyusun Produk Utama (Main Product Revision), Uji Lapangan (Uji Coba Skala Besar) (Main Field Testing) dan Revisi Produk Final (Final Product Revision).

Pada tahap studi pendahuluan berupa observasi untuk mengumpulkan informasi. Tahap selanjutnya yaitu perencanaan, pada tahap ini ada 3 langkah yaitu perumusan tujuan, studi literatur dan perancangan desain modul. Pada tahap mengengambangkan produk awal ini dilakukan 3 tahapan, yang pertama yaitu penyusunan modul pembelajaran dan menghasilkan draf 1 modul Biologi berbasis etnobotani masyarakat Kediri dan sekitarnya. Yang kedua mempersiapkan instrumen dan rubrik validasi. Yang ketiga yaitu validasi ahli dan revisi, tahap ini merupakan penilaian dari pengembangan modul Biologi draf 1 oleh ahli materi, pengembangan, media dan pengguna (guru Biologi kelas X). Jika hasil analisis menunjukkan pada kategori valid-sangat valid, dapat diartikan bahwa modul dapat digunakan tanpa revisi dan dilanjutkan uji coba skala kecil. Jika hasil analisis menunjukkan kurang valid, dapat diartikan bahwa modul dapat digunakan dengan dilakukan revisi kecil. Dan jika hasil analisis menunjukkan tidak valid, dapat diartikan bahwa modul dapat digunakan dengan dilakukan revisi besar. Maka kegiatan yang harus dilakukan yaitu merevisi terlebih dahulu dan kembali meminta pertimbangan dari validator (Andriyani et al., 2020).

Tahap selanjutnya dilakukan uji coba skala kecil pada 9 siswa (masing-masing 3 siswa berprestasi tinggi, sedang dan rendah). Pada uji skala kecil ini dilakukan pengambilan data uji keterbacaan menggunakan cloze test. Hasil cloze test tersebut digunakan untuk melihat hasil uji keterbacaan setelah membaca modul yang telah dikembangkan. Jika hasil analisis menunjukkan pada kategori independen (mudah), dapat diartikan bahwa modul tidak perlu revisi dan siap digunakan. Jika hasil analisis menunjukkan pada kategori intruksional (sedang), dapat diartikan bahwa modul perlu 
revisi kecil untuk penyempurnaan sebelum digunakan. Dan jika hasil analisis menunjukkan pada kategori frustasi (sulit), dapat diartikan bahwa modul perlu direvisi dalam skala besar sebelum digunakan (Humairoh et al., 2016).

Tahap selanjutnya yaitu uji coba skala besar yang dilakukan pada 36 siswa dalam 1 kelas. Pada uji coba skala besar dengan memberikan angket respon siswa, pre-test dan post-test untuk mengetahui kepraktisan dan keefektifan modul yang telah dikembangkan. Penyebaran angket respon siswa digunakan untuk uji kepraktisan modul kepada siswa kelas $\mathrm{X}$ yang menjadi responden. Jika hasil analisis respon siswa menunjukkan praktis-sangat praktis, dapat diartikan bahwa modul dapat digunakan tanpa revisi. Jika hasil analisis menunjukkan cukup praktis, dapat diartikan bahwa modul dapat digunakan dengan dilakukan revisi kecil. Dan jika hasil analisis menunjukkan tidak praktis-kurang praktis, dapat diartikan bahwa modul dapat digunakan dengan dilakukan revisi besar.

Pre-test diberikan sebelum siswa membaca modul yang telah dikembangkan, sedangkan post-test diberikan setelah siswa belajar menggunakan modul. Hasil efektivitas dari hasil belajar berupa nilai pre-test dan post-test dengan menggunakan modul akan dianalisis dan diinterpretasikan menggunakan rumus Normalized gain. Jika hasil analisis menunjukkan pada kriteria tingi, dapat diartikan bahwa modul dapat digunakan tanpa revisi. Jika hasil analisis menunjukkan pada kriteria sedang, dapat diartikan bahwa modul dapat digunakan dengan dilakukan revisi kecil. Dan jika menunjukkan pada kriteria rendah, dapat diartikan bahwa modul dapat digunakan dengan dilakukan revisi besar. Selanjutnya, hasil kriteria normalized gain kemudian dikonsultasikan ke dalam kategori tafsiran efektifitas normalized gain untuk mengetahui efektifitas penggunaan modul pembelajaran menggunakan $\mathrm{N}$-gain score yang telah dipersenkan (\%). Sehingga dapat ditarik kesimpulan bahwa modul dapat dikatakan efektif, cukup efektif, kurang efektif atau tidak efektif dalam meningkatkan hasil belajar siswa (Solikha et al., 2020).

\section{HASIL DAN PEMBAHASAN}

\section{Studi Pendahuluan dan Pengumpulan Data (research and information collecting)}

Pada tahap ini dilakukan beberapa tahapan yaitu mengkaji kurikulum dan materi dan melakukan analisis kebutuhan dengan memberikan angket pada siswa, guru Biologi di SMA Negeri 1 Plemahan dan pengkaji budaya di Kediri.

\section{Perencanaan (planning)}

Tahap selanjutnya yaitu perencanaan, pada tahap ini ada 3 langkah yaitu perumusan tujuan, studi literatur dan perancangan desain modul. Perumusan dari tujuan pembelajaran ini didasari oleh kurikulum, standar kompetensi, kompetensi dasar dan indikator pembelajaran. Studi literatur ini dilakukan dengan tujuan untuk menemukan materi-materi penting yang digunakan untuk pengembangan modul pembelajaran. Perancangan desain modul yang dibuat khusus pada KD 3.8 yaitu menerapkan prinsip, klasifikasi untuk menggolongkan tumbuhan ke dalam divisio berdasarkan pengamatan morfologi dan metagenesis tumbuhan serta mengaitkan peranannya dalam kelangsungan kehidupan di bumi. 


\section{Mengembangkan Produk Awal (develop preliminary from of product)}

Pada tahap ini terdapat 3 tahapan, yaitu yang pertama penyusunan modul pembelajaran dan menghasilkan draf 1 . Draf 1 merupakan produk sementara dengan rancangan yang direncanakan oleh peneliti. Beberapa bagian gambar desain dari modul yang telah dikembangkan dapat dilihat pada Gambar 1 berikut.
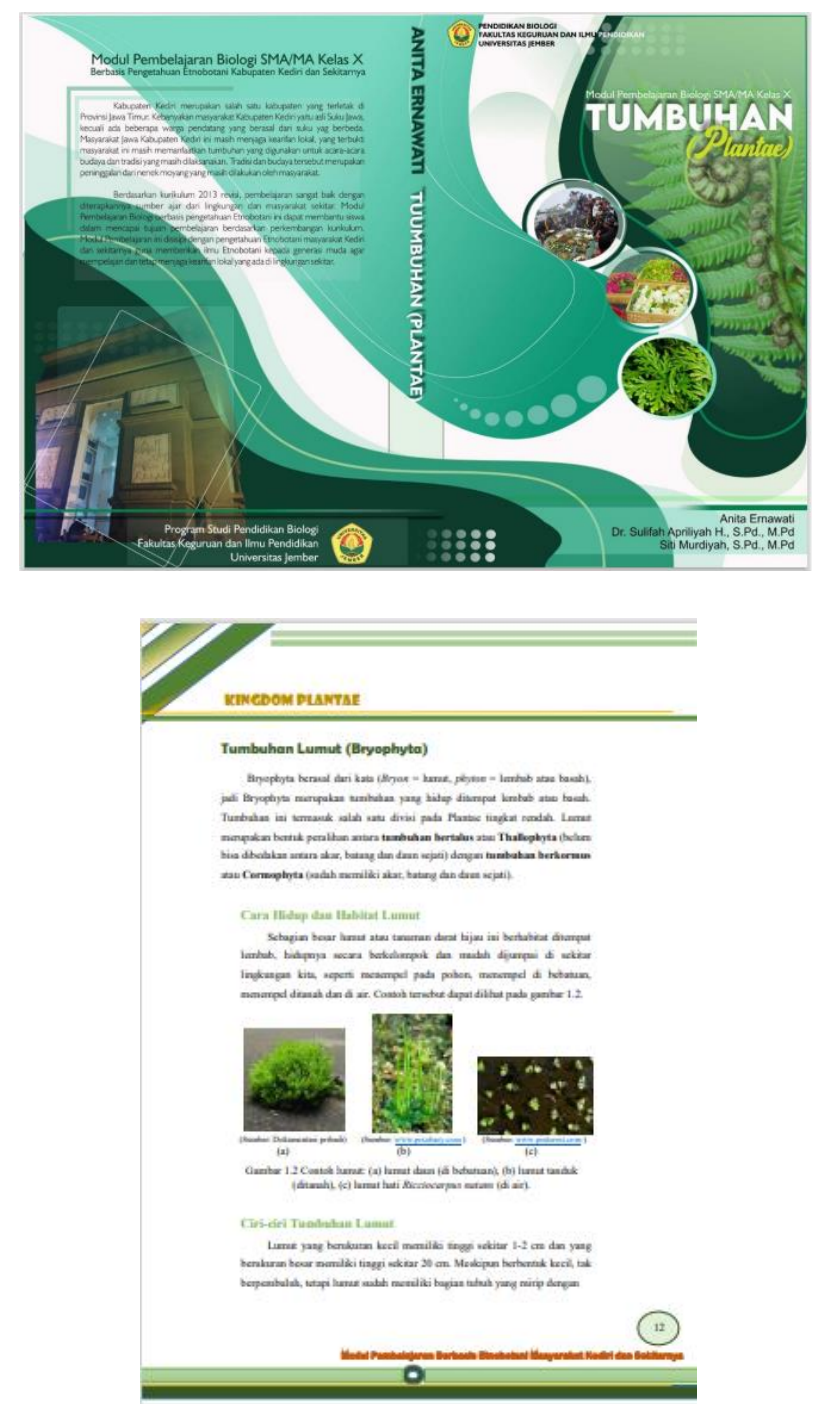

Gambar 1. Desain bagian modul (Draf 1)

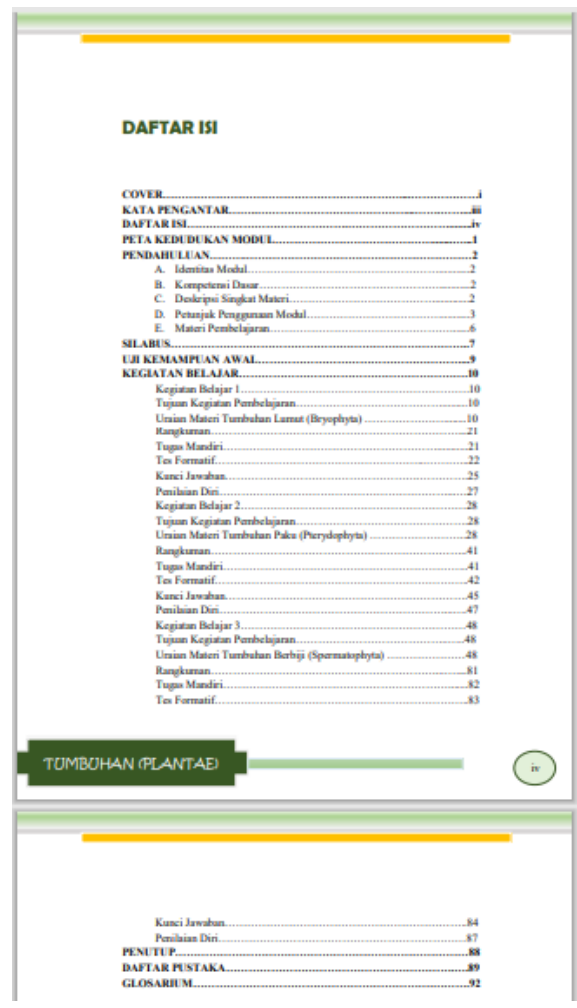

Yang kedua yaitu persiapan instrumen dan rubrik validasi Instrumen yang digunakan untuk melakukan validasi terhadap modul berupa angket validasi ahli materi, media, pengembangan dan pengguna. Angket analisis kebutuhan berupa angket kebutuhan siswa, guru dan pengkaji budaya. Sedangkan instrumen yang digunakan untuk melakukan uji coba skala kecil (keterbacaan) berupa cloze test dan uji coba skala besar (efektivitas) berupa pre test, post test serta angket respon siswa.

Tahap yang ketiga yaitu validasi ahli dan revisi. Tahap validasi ini dilakukan oleh validasi ahli materi, pengembangan, media dan pengguna. Pada tahap ini menghasilkan draf 2 yang sudah divalidasi oleh ahli yang diikuti dengan beberapa revisi untuk perbaikan, sehingga modul yang dikembangkan teruji kevalidannya. Setelah dilakukan 
beberapa revisi untuk perbaikan, selanjutnya dapat berlanjut pada uji kepraktisan dan keefektifan.

a. Hasil penilaian validator ahli

Tabel 1. Hasil Penilaian Validator Ahli

\begin{tabular}{lcc}
\hline \multicolumn{1}{c}{ Validator Ahli } & Persentase $\mathbf{( \% )}$ & Tingkat Validitas \\
\hline Materi & 98,82 & Sangat valid \\
Pengembangan & 80 & Sangat valid \\
Media & 88 & Sangat valid \\
Pengguna & 95,25 & Sangat valid \\
\hline
\end{tabular}

Berdasarkan analisis data pada Tabel 1 . hasil penilaian validator ahli yaitu pada ahli materi persentasenya sebesar $98,82 \%$ dan diinterpretasikan dalam kategori sangat valid; menurut ahli pengembangan persentasenya sebesar $80 \%$ dan diinterpretasikan dalam kategori sangat valid; menurut ahli media persentasenya sebesar $88 \%$ dan diinterpretasikan dalam kategori sangat valid; dan menurut ahli pengguna persentasenya sebesar 95,25\% dan diinterpretasikan dalam kategori sangat valid.

Hasil dari keempat validator ahli masing-masing berada pada tingkat sangat valid. Sehingga dapat dilanjutkan ke tahap selanjutnya yaitu uji coba dengan menambahkan/memperbaiki data dari beberapa komponen sesuai saran validator terhadap modul.

\section{Uji Coba Produk dan Revisi Final}

a. Uji coba skala kecil

Uji coba skala kecil bertujuan untuk mengetahui hasil keterbacaan dari modul. Hasil uji keterbacaan oleh 9 siswa dapat dilihat pada Tabel 2.

Tabel 2. Hasil Uji Skala Kecil (Keterbacaan)

\begin{tabular}{cc}
\hline Rata-Rata Persentase Skor Cloze Test (\%) & Tingkat Keterbacaan \\
\hline $89,7 \%$ & Independen/Mudah \\
\hline
\end{tabular}

Berdasarkan Tabel 2. diketahui rata-rata penilaian cloze test yang telah diberikan, rata-rata tersebut sebesar $89,7 \%$ dan diinterpretasikan dalam tingkat keterbacaan independen/mudah yang diartikan bahwa modul siap digunakan tanpa adanya revisi. Sehingga dapat dilanjutkan pada tahap selanjutnya, yaitu tahap uji coba skala besar untuk mengetahui kepraktisan dan keefektifan modul yang telah dikembangkan.

b. Uji kepraktisan modul

Tahap uji kepraktisan dilakukan kepada seluruh siswa dalam 1 kelas di SMA Negeri 1 Plemahan. Siswa selaku responden diberikan angket respon siswa setelah membaca modul yang telah dikembangkan. Hasil respon siswa terhadap modul yang telah dikembangkan dapat dilihat pada Tabel 3.

Tabel 3. Hasil Analisis Respon Siswa

\begin{tabular}{cc}
\hline Rata-Rata (\%) & Interpretasi \\
\hline $97,5 \%$ & Sangat Praktis \\
\hline
\end{tabular}

Berdasarkan tabel 3, dapat diketahui bahwa rata-rata penilaian respon siswa pada semua aspek yaitu sebesar 97,5\%. Dari hasil rata-rata persentase tersebut, dapat diinterpretasikan dalam kategori sangat praktis.

c. Uji keefektifan modul 
Tahap uji keefektifan ini merupakan tahap uji coba skala besar yang dilakukan kepada seluruh siswa kelas X MIPA 5 di SMA Negeri 1 Plemahan. Pada saat uji coba, 36 siswa mempelajari modul pembelajaran secara semi mandiri. Hasil pre-test dan posttest siswa dapat dilihat pada Tabel 4.

Tabel 4. Hasil Pre-test dan Post-test

\begin{tabular}{cccccc}
\hline & Pre-test & Post-test & Selisih & Normalized gain & Kriteria \\
\hline Jumlah & 2035 & 2932,5 & 897,5 & 20,38 & \\
\cline { 1 - 4 } Rata-rata & 56,52 & 81,45 & 24,93 & 0,58 & Sedang \\
\hline \multicolumn{7}{c}{ Nilai pre-test $<$ Nilai post-test } \\
\hline \multicolumn{7}{c}{}
\end{tabular}

Berdasarkan Tabel 4 dapat diketahui bahwa rata-rata nilai pre-test sebesar 56,52; rata-rata nilai post-test sebesar 81,45 dengan rata-rata selisih peningkatan yaitu sebesar 24,93. Hasil yang telah didapatkan tersebut kemudian dianalisis menggunakan rumus Normalized gain, hal ini digunakan untuk mengetahui kriteria peningkatannya.

Rata-rata peningkatan berdasarkan Normalized gain didapatkan sebesar 0,58 yang berada pada kriteria sedang. Kemudian diubah ke dalam tabel tafsiran efektifitas menurut menjadi persentase dan didapatkan skor 58\% yang termasuk dalam kategori cukup efektif untuk meningkatkan hasil belajar siswa. Hal tersebut juga didukung dengan tampilan modul yang menarik, sehingga siswa termotivasi untuk belajar.

\section{PEMBAHASAN}

Tahap studi pendahuluan dan pengumpulan data ini melakukan observasi untuk mengumpulkan informasi. Peneliti mempelajari kurikulum pada mata pelajaran Biologi Kelas X yang digunakan oleh SMA Negeri 1 Plemahan. Kurikulum yang digunakan oleh SMA Negeri 1 Plemahan yaitu Kurikulum 2013 revisi ini digunakan sebagai bahan dasar pengembangan modul. Materi yang digunakan yaitu Pokok Bahasan Tumbuhan (Plantae) di kelas $\mathrm{X}$ yang dihubungkan dengan kearifan lokal etnobotani yaitu tumbuhan yang digunakan sebagai bahan obat tradisional dan acara adat istiadat oleh masyarakat Jawa di Kabupaten Kediri dan sekitarnya. Sehingga siswa juga akan mengetahui manfaat adanya kekayaan alam dilingkungan sekitar khususnya tumbuhan, serta pelestarian tumbuhan tersebut dengan baik agar kearifan lokal tetap terjaga dan pemanfaatan oleh masyarakat lokal khususnya tumbuhan juga terjaga dengan baik. Setelah itu dilakukan analisis kebutuhan berupa angket, hasil analisis kebutuhan menyatakan bahwa guru, siswa dan salah satu pengkaji budaya di Kabupaten Kediri setuju dengan dilakukannya pengembangan modul pembelajaran berbasis pengetahuan Etnobotani.

Hal penting dalam perencanaan yaitu menyatukan tujuan yang harus dicapai dari produk yang akan dikembangkan (Jonan, 2020). Tujuan yang hendak dicapai dari dilakukannya pengembangan modul pada tahap ini yaitu dapat mengetahui kemampuan yang dicapai oleh siswa setelah menggunakan modul yang sudah dikembangkan. Selanjutnya melakukan studi literatur, peneliti mencari dan mengumpulkan data melalui studi literatur untuk mengkaji hasil penelitian-penelitian terdahulu guna dapat mengetahui keluasan dan kedalaman modul yang akan dikembangkan sesuai dengan kondisi siswa serta tujuan dari pembelajaran. Kemudian juga mengetahui bahwasanya pada penelitian terdahulu belum ada penelitian pengembangan Modul Pembelajaran Biologi SMA Kelas X Berbasis Kearifan Lokal Etnobotani Masyarakat Kediri dan sekitarnya. 
Desain modul yang dirancamg oleh peneliti yaitu didalam uraian materi akan disisipkan informasi mengenai ilmu Etnobotani masyarakat Kediri dan sekitarnya. Kemudian dilengkapi dengan ilustrasi berupa tabel, gambar dan sejenisnya. Diberikan QR Code pada setiap sub bab yang berisi penjelasan materi yang diambil disalah satu akun youtube yang sudah terverifikasi kebenarannya untuk memudahkan siswa dalam memahami materi. Tahap pengembangan produk awal meliputi menyusun modul yang menghasilkan draf 1 . Modul telah disusun menggunakan kalimat yang disesuaikan dengan usia dan pengalaman pembaca dan meminimalisir adanya kesalahan tulisan, serta dilengkapi dengan tabel, gambar dan sejenisnya secara proporsional. Kemudian dilanjutkan mempersiapkan instrumen dan rubrik validasi dan dilanjutakan validasi ahli dan revisi. Tahap ini merupakan penilaian dari pengembangan modul Biologi draf 1 .

Uji validasi ini meliputi validasi ahli materi, pengembangan, media dan pengguna. Validator ahli merupakan 3 dosen Pendidikan Biologi yang dipilih sesuai dengan bidagnya dan pengguna yang merupakan guru Biologi SMA Negeri 1 Plemahan. Validasi dilakukan dengan cara memberikan draf 1 modul dan lembar instrumen validasi kepada validator. Hasil penilaian uji kevalidan dari keempat validator ahli menunjukkan bahwa modul berada pada tingkat sangat valid.

Uji kevalidan oleh validator ahli memiliki tujuan untuk mendapatkan pendapat/saran dari ahli tentang produk yang dibuat berdasarkan aspek-aspek tertentu (Anggreni et al., 2020 dan Jaya et al., 2020). Hasil penilaian dan saran/masukan dari validator dapat menjadi bahan perbaikan, sehingga menghasilkan modul yang sangat valid (Purwanti et al., 2021). Draf 1 yang telah divalidasi oleh ahli dan selesai diperbaiki sesuai dengan saran validator menghasilkan draf 2. Draf 2 tersebut dilanjutkan ke tahap uji coba. Terdapat 2 jenis uji coba yang dilaksanakan, yaitu uji coba skala kecil dan skala besar.

Uji coba skala kecil dengan 9 siswa sebagai responden diberi modul yang telah dikembangkan (draf 2). Setelah kegiatan belajar dengan membaca modul selesai, siswa diberikan cloze test. Cloze test ini bertujuan untuk melihat hasil uji keterbacaan siswa setelah membaca modul yang telah dikembangkan. Hasil cloze test yang dikerjakan siswa kemudian dianalisis untuk menunjukkan kelayakan modul tersebut jika digunakan dan perlu/tidaknya dilakukan revisi terhadap draf 2. Hasil tersebut menunjukkan bahwa uji keterbacaan yang didapatkan yaitu dalam kategori independen/mudah. Kategori independen atau yang artinya mudah tersebut menjelaskan bahwa modul dapat digunakan siswa dalam proses belajar secara mandiri. Modul yang dihasilkan (draf 2) dapat dipahami siswa dengan mudah, tidak perlu dilakukan revisi dan modul siap digunakan, sehingga menghasilkan draf 3. Draf 3 dilanjutkan ketahap berikutnya yaitu uji coba skala besar.

Seluruh siswa dalam 1 kelas X MIPA 5 di SMA Negeri 1 Plemahan yang dilibatkan dalam uji coba skala besar. Kegiatan belajar dilakukan via zoom meeting, siswa terlebih dahulu diberikan pre-test dengan soal uraian berjumlah 5 soal mengenai materi tumbuhan (Plantae) dan berkaitan dengan kearifan lokal masyarakat Kediri dan sekitarnya dalam kehidupan sehari-hari. Setelah selesai melakukan pre-test, siswa diberikan Modul Biologi SMA Kelas X Berbasis Etnobotani Masyarakat Kediri dan Sekitarnya untuk dibaca dan pelajari. Selama 1 minggu siswa mempelajari materi didalam modul dan mengerjakan soal-soal yang ada didalam modul. Dipertemuan selanjutnya, via whatsaap grup siswa diperkenankan menanyakan hal-hal yang belum jelas terkait modul yang dikembangkan. Setelah itu, dilakukan post-test dengan soal yang sama seperti pre-test. 
Pre-test merupakan test yang diberikan kepada siswa sebelum proses pembelajaran yang bertujuan untuk mengetahui kemampuan awal siswa, sedangkan post-test merupakan test yang diberikan kepada siswa setelah pelajaran/materi disampaikan yang bertujuan untuk mengetahui tingkat penguasaan siswa terhadap materi pada modul. Kemudian siswa diminta untuk mengisi angket respon siswa terhadap modul yang telah dikembangkan. Siswa memberikan penilaian terhadap modul untuk tiap aspek, setelah itu didapatkan hasil angket respon siswa serta hasil nilai pretest dan post-test dari hasil uji coba skala besar sebagai alat ukur pemahaman siswa mengenai modul yang telah dikembangkan. Hal ini dilakukan untuk mengetahui sejauh mana modul dapat dipahami siswa dan memberikan informasi kepada siswa.

Hasil penilaian respon siswa dianalisis untuk mengetahui respon siswa terhadap modul yang telah dikembangkan perlu/tidaknya dilakukan revisi terhadap modul. Hasil tersebut menunjukkan bahwa respon siswa terhadap modul berada dalam kategori sangat praktis. Hal ini dikarenakan kepraktisan dapat mengacu pada kondisi modul yang dikembangkan dapat dengan mudah digunakan oleh siswa. Sehingga pembelajaran yang dilakukan siswa lebih bermakna, menarik, menyenangkan dan berguna bagi kehidupan siswa serta dapat meningkatkan kreativitas siswa dalam belajar dan memiliki derajat keefektifan terhadap hasil belajar siswa (Alfiriani \& Hutabri, 2017).

Hasil belajar dapat diartikan sebagai hasil akhir yang diperoleh siswa setelah menyelesaikan proses belajar yang dapat digunakan ukuran, apakah siswa tersebut sudah berhasil dalam memahami materi atau belum. Tes hasil belajar dapat mengukur keefektifan produk yang dibuat. Hasil belajar siswa dapat ditandai dengan skala nilai berupa huruf, simbol dan angka (Syachtiyani \& Trisnawati, 2021).

Hasil belajar siswa diperoleh dari nilai pre-test dan post-test yang telah dianalisis menggunakan rumus Normalized gain, hasil peningkatan yang didapatkan sebesar 0,58 dan tergolong dalam kategori tingkat sedang. Kemudian diubah ke dalam tabel tafsiran efektifitas menjadi persentase dan didapatkan skor 58\% yang termasuk dalam kategori cukup efektif. Hal tersebut dipengaruhi oleh minat belajar masing-masing siswa yang berbeda, kurangnya persiapan yang matang dan siswa kurang fokus dalam pembelajaran menggunakan modul. Walaupun dalam kategori sedang, hal tersebut dapat ditingkatkan lagi dengan memberikan motivasi kepada siswa untuk belajar mandiri menggunakan modul. Kesimpulan yang didapatkan bahwa modul dapat dikatakan cukup efektif karena dapat meningkatkan hasil belajar siswa. Hal tersebut juga didukung dengan tampilan modul yang menarik, materi yang disajikan dilengkapi dengan banyak gambar sehingga mudah dipahami dan siswa termotivasi untuk belajar.

Hasil analisis respon siswa dan hasil belajar berupa pre-test dan post-test merupakan tahap akhir pada penelitian. Hal tersebut menunjukkan bahwa modul dapat dipahami siswa dan memberikan informasi kepada siswa, penyajian materi dan isinya jelas, tampilan yang menarik dan memberikan manfaat bagi siswa karena merupakan informasi baru yang sebelumnya jarang/belum diketahui oleh siswa. Selain itu cukup efektif dan mampu meningkatkan hasil belajar siswa. Oleh karena itu, modul yang dihasilkan (draf 4) setelah uji coba skala besar ini dapat digunakan tanpa revisi. Modul yang telah dikembangkan cukup efektif dan dapat dijadikan sebagai modul yang dapat digunakan siswa dalam belajar mandiri maupun semi mandiri. Akan tetapi, saran dan komentar dari pembaca diharapkan oleh penulis demi meningkatkan kualitas dan efektifitas modul yang telah dikembangkan. 


\section{SIMPULAN}

Modul Biologi SMA Kelas X Berbasis Etnobotani Masyarakat Kediri dan Sekitarnya teruji sangat valid, sangat praktis dan cukup efektif dalam meningkatkan hasil belajar siswa.

\section{DAFTAR RUJUKAN}

Adinugraha, F., Ponto, A. I., \& Munthe, T. RM. (2020). Potensi Kebudayaan Betawi Sebagai Pendekatan Kearifan Lokal Dan Budaya Dalam Pembelajaran Biologi. EDUPROXIMA : Jurnal Ilmiah Pendidikan IPA, 2(2), 56. https://doi.org/10.29100/eduproxima.v2i2.1625

Adinugraha, F., \& Ratnapuri, A. (2020). Modul Keanekaragaman Hayati dengan Pendekatan Kearifan Lokal dan Budaya di Kabupaten Purworejo. SAP (Susunan Artikel Pendidikan), 5(1), 28. https://doi.org/10.30998/sap.v5i1.6534

Alfiriani, A., \& Hutabri, E. (2017). Kepraktisan dan Keefektifan Modul Pembelajaran BIilingual Berbasis Komputer. Jurnal Kependidikan, 1(1), 16.

Alimah, S. (2019). Kearifan Lokal Dalam Inovasi Pembelajaran Biologi: Strategi Membangun Anak Indonesia Yang Literate dan Berkarakter Untuk Konservasi Alam. Jurnal Pendidikan Hayati, 5(1), 2-3. https://doi.org/10.33654/jph.v5i1.574

Andriyani, F., Saraswati, R. R., Melasari, D., Putri, A., \& Sumardani, D. (2020). Media Pembelajaran Monopoli: Media Edukasi Materi Struktur dan Fungsi Jaringan Tumbuhan. Jurnal Pembelajaran dan Biologi Nukleus, 6(1), 86.

Anggreni, N. L. P., Subagia, I. W., \& Rapi, N. K. (2020). Pengembangan Validitas, Efektifitas Dan Kepraktisan Model Pembelajaran Blended Learning Untuk Meningkatkan Hasil Belajar Ipa Terapan. Jurnal Ilmiah Pendidikan dan Pembelajaran, 4(3), 332. https://ejournal.undiksha.ac.id/index.php/JIPP/article/view/26109

Hafida, S. H. N., Ariandi, A. P., Ismiyatin, L., Wulandari, D. A., Reygina, N., Setyaningsih, T., Setyawati, L., Sochiba, S. L., \& Amin, M. A. K. (2020). Pengenalan Etnobotani melalui Pembuatan Herbarium Kering di Lingkungan Sekolah MI Muhammadiyah Plumbon, Wonogiri. Buletin KKN Pendidikan, 2(2), 79. https://doi.org/10.23917/bkkndik.v2i2.10776

Humairoh, Z., Nurchasanah \& Mudiono, A. (2016). Keterbacaan Buku Teks Kelas Iv Dan V Sd Dalam Kurikulum 2013. Jurnal Pendidikan: Teori, Penelitian, Dan Pengembangan, 1(5), 167. https://doi.org/10.17977/jp.v1i2.6118

Jaya, I. M. S., Dantes, N., \& Gunamantha, I. M. (2020). Pengembangan Instrumen Kemampuan Berpikir Kritis Pada Pembelajaran Ipa Siswa Kelas V SD. Jurnal_ep, 10(2), 96. https://repo.undiksha.ac.id/id/eprint/4298

Jonan, Y. R. (2020). Pengembangan Rubrik Penskoran pada Asesmen Otentik untuk Materi Volume dan Luas Balok. Journal of Medives: Journal of Mathematics Education IKIP Veteran Semarang, 4(2), 279.

Khulsum, U., Hudiyono, Y., \& Sulistyowati, E. D. (2019). Pengembangan Bahan Ajar Menulis Cerpen dengan Media Storyboard pada Siswa Kelas X SMA. Diglosia: Jurnal Kajian Bahasa, Sastra, Dan Pengajarannya, 1(1), 2. 
https://doi.org/10.30872/diglosia.v1i1.4

Purwanti, W., Mayasari, D., \& Munfarikhatin, A. (2021). Pengembangan Lembar Kerja Siswa Model Kooperatif Tipe Numbered Heads Together Untuk Meningkatkan Hasil Belajar. Alifmatika: Jurnal Pendidikan Dan Pembelajaran Matematika, 3(1), 77. https://doi.org/10.35316/alifmatika.2021.v3i1.70-79

Soleh, Sumardi, \& Arsana, I. M. (2020). Pengembangan modul pembelajaran injector cleaner untuk menunjang praktikum perkuliahan mahasiswa jurusan teknik mesin. JVTE: Journal of Vocational and Technical Education, 02(01), 2.

Solikha, N., Suchainah \& Rasyida, I. (2020). Schoology Terhadap Peningkatan Keaktifan Dan Hasil Belajar Siswa X Ips Man Kota Pasuruan. Jurnal Ilmiah Edukasi \& Sosial, 11(1), 38. https://jiesjournal.com/index.php/jies/article/view/221

Syachtiyani, W. R., \& Trisnawati, N. (2021). Analisis Motivasi Belajar Dan Hasil Belajar Siswa Di Masa Pandemi Covid-19. Prima Magistra: Jurnal Ilmiah Kependidikan, 2(1), 93. https://doi.org/10.37478/jpm.v2i1.878

Yermon \& Eliza, F. (2020). Pengembangan Modul Pembelajaran Dasar Listrik dan Elektronika Untuk Kelas X TITL SMK Negeri 1 Padang. JTEV (Jurnal Teknik Elektro Dan Vokasional), 6(2), 228.

https://doi.org/10.24036/jtev.v6i2.109033 